\title{
Personalized assessments for the betterment of performance in Biology
}

\author{
Sai Shri Ramamurthy \\ Sree Venkateshwara Pre-University College, Madiwala, Bengaluru
}

\begin{abstract}
This paper discusses about the action research done on the types of assessments in learning Biology by the senior secondary students (Pre University College) in a rural district near Bangalore. As there are different types of learners and not all the students learn in the same pace, one size fits all approach doesn't work to assess learning. During the pre test period all the students were given the same type of standardized assessments and the class average was $33 \%$. The strength of the class was 15 students, the attention span of the students was carefully studied, their interests was also learnt by the teacher after which she devised personalized assessments for the betterment of the performance of the students in Biology. When the post test scores were studied, the class average was $86 \%$.
\end{abstract}

Keywords : think, link, relate, learn, students with learning disabilities, collaborative learning, learning in regional language.

\section{Introduction}

The ultimate aim of conducting assessments is to assess the learning, knowledge and skills of the students. So the bar set for each student to measure his/her achievement differs helping the students improve and excel. A variety of methods of assessments have been used and the methods discussed here were found to help the improvement in the performance.

The criteria of giving marks was different for each student. Each student was appreciated for every step of progress made and the fast learners were challenged to excel. Every time a test was conducted, the marks obtained by each student in each question was recorded, mistakes were analyzed and appropriate guidance was given to the student, sometimes the concept was taught using a different teaching methodology, sometimes collaborative and blended learning techniques were employed.

\section{Assessment for the slow learners}

The methods of assessment used for the slow learners were, as the first step they were asked to mark the parts with respect to the plant and human reproductive system, once they learnt the parts of the reproductive system, they were then helped to learn the role and function played by each part. Concepts were given in bite sized bits. They were made to think, link and relate the concepts being taught. They were asked to discuss about the concept in their regional language. Then they were provided help to translate it into English, they were given help until they were able to independently answer the questions given in the standardized tests during the practice sessions. 
With respect to genetics, $3 \mathrm{~d}$ printing models were used to make them understand the structure of DNA, the slow learners were made to explain the structure of the DNA, first in the regional language and then English. Concepts were broken into bite sized bits and pieces, they were made to answer the questions with one word answers and then they were made to think, Link and relate. With respect to Biology in human welfare, dealing with agricultural sciences and animal husbandry, as the study was done in a rural district near Bangalore, they were asked to learn from their agrarian friends and were made to explain whatever the students have learnt.

\section{Assessment for moderate learners}

As it's a rural district, to make the students comfortable, they were allowed to write answers as concept maps, mind maps and flow charts. They were taught how to construct maps and flow charts and with respect to the plant and animal reproductive systems they were allowed to write about the role and function of each part in a few sentences beside the parts. (Grammatical errors were not taken into account while giving marks). With respect to moderate learners, as they made progress, at each step they were given guidance.

\section{Assessment for the fast learners}

For the fast learners, marking scheme followed by the teacher for the standardized tests was very strict. They were trained to answer objective questions mainly for the competitive exams like the medical entrance exam. They were also given questions that involved mathematical calculations.

\section{Collaborative learning}

To help the slow learners pick up pace and to channelize the energy of the fast learners, the students were carefully divided into groups that had slow learners, fast learners and moderate learners. They were made to make posters and present it. The posters were made by the fast learners and once they got the approval from the teacher, the fast learners helped the slow learners and the moderate learners. The moderate learners were made to present it in English and the slow learners were asked questions about the concept being discussed.

\section{Results and discussions}

The strength of the class was 15 students with all types of learners, slow learners, learners with learning disabilities, moderate learners and fast learners. As the strength of the class was appropriate for action research it aided the research study, the main objective was to encourage the students and help them improve and excel. The time taken to teach the concepts and help the students learn was carefully planned. To improvise the performance of the students the time taken to revise the concepts was utilized well. The main motive was to help each student feel confident to face the board exams, to help the students learn for the exams and for life and to avoid rote learning. There was a promising progress in the standardized tests conducted by the teacher, in the post test, the class average was $86 \%$. The students were confident in approaching the exams. The slow learners and students with learning disabilities were found to fare well independently and the slow learners and the students with learning disabilities fared well in the 


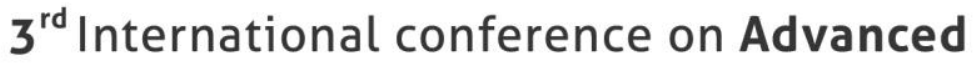

board exams as well and the fast learners and moderate learners have cleared the competitive exams.

*Board exams : exams conducted by the education boards, with respect to this action research, it was Pre University Education Board of Karnataka, India.

\section{Reference :}

1. The Use of Three-Option Multiple Choice Items for Classroom Assessment 2018 Erkan Hasan Atalmış10.21449/ijate.421167 International Journal of Assessment Tools in Education

2. Classroom Assessment Techniques. A Handbook for Faculty. K Patricia Cross, Thomas A Angelo The National Center for Research to Improve Postsecondary Teaching and Learning, 2400 School of Education Bldg., The University of Michigan, Ann Arbor, MI 48109, 1988.

3.Sai Shri Ramamurthy, "Assessment of the types of Assessments in Learning Biology and the Interest of the Middle School Students towards the Subject", International Journal of Science and

Research

(IJSR),

https://www.ijsr.net/search_index_results_paperid.php?id=SR20803105500, Volume 9 Issue 8, August 2020, $238-239$ 